\title{
Diabetes causes marked changes in lymphocyte metabolism
}

\author{
R Otton, J R Mendonça and R Curi \\ Department of Physiology and Biophysics, Institute of Biomedical Sciences, University of São Paulo, Av. Prof. Lineu Prestes, 1524, 05508-900 Butantan, \\ São Paulo, São Paulo, Brazil \\ (Requests for offprints should be addressed to R Otton; Email: rose@fisio.icb.usp.br)
}

\begin{abstract}
An enhanced susceptibility to infections is well known to occur in a poorly controlled diabetic state. Since glucose and glutamine are essential for lymphocyte function, we investigated whether their metabolism is changed in lymphocytes obtained from mesenteric lymph nodes of alloxan-induced diabetic rats $(40 \mathrm{mg} / \mathrm{kg}$ body weight). The activities of hexokinase, phosphofructokinase, glucose-6-phosphate dehydrogenase (G6PDH), citrate synthase and phosphate-dependent glutaminase were determined. Decarboxylation of metabolites $\left[\mathrm{U}_{-}{ }^{14} \mathrm{C}\right]-$, $\left[1-{ }^{14} \mathrm{C}\right]-$ and $\left[6-{ }^{14} \mathrm{C}\right]$-glucose, $\left[1-{ }^{14} \mathrm{C}\right]-$ and $\left[2-{ }^{14} \mathrm{C}\right]-$ pyruvic acid, $\left[\mathrm{U}_{-}{ }^{14} \mathrm{C}\right]$-palmitic acid and $\left[\mathrm{U}_{-}{ }^{14} \mathrm{C}\right]$-glutamine was evaluated in incubated lymphocytes isolated from mesenteric lymph nodes. The measurements were carried out in cells following three experimental protocols: (1) lymphocytes freshly obtained from control and alloxaninduced diabetic rats, (2) lymphocytes from insulin-treated
\end{abstract}

(2 U/rat per day) diabetic rats and (3) lymphocytes obtained from control and diabetic rats and cultured in the presence of insulin $(1 \mathrm{mU} / \mathrm{ml})$ for $6 \mathrm{~h}$. The activities of hexokinase, G6PDH and citrate synthase were decreased by the diabetic state, whereas that of phosphofructokinase was raised. Decarboxylation of $\left[\mathrm{U}_{-}{ }^{14} \mathrm{C}\right]-$ and $\left[6-{ }^{14} \mathrm{C}\right]-$ glucose, $\left[1-{ }^{14} \mathrm{C}\right]-$ and $\left[2-{ }^{14} \mathrm{C}\right]-$ pyruvate and $\left[\mathrm{U}_{-}{ }^{14} \mathrm{C}\right]-$ glutamine were also decreased in lymphocytes from diabetic rats, whereas [ $\left.\mathrm{U}_{-}{ }^{14} \mathrm{C}\right]$-palmitic acid decarboxylation was increased. Insulin administration in vivo or added to the culture medium reversed the changes observed in freshly obtained lymphocytes. Alloxan-induced diabetes did change lymphocyte metabolism and this may be an important mechanism leading to impairment of lymphocyte function.

Journal of Endocrinology (2002) 174, 55-61

\section{Introduction}

An enhanced susceptibility to infections is well known to occur in a poorly controlled diabetic state (Kraine \& Tisch 1999). The incidence of a recognized group of rare infections is definitely high in diabetes mellitus or confined almost entirely to diabetic patients (Larkin et al. 1985). Infectious diseases, particularly tuberculosis, were a major cause of death among diabetic patients before the advent of insulin therapy (Eliopoulos 1995). Critical evaluations of the topic suggest that infections in general are more difficult to eliminate in the diabetic host (Garcia-Leme 1989). The reasons why diabetic patients present an increased susceptibility to frequent and prolonged infections, however, remain to be fully determined.

Mature lymphocytes recirculate via blood and lymph through lymphoid tissues in a relatively quiescent state until stimulated to proliferate during, for example, a bacterial or viral infection. T-cell blastic transformation stimulated by phytohaemagglutin (Korfel et al. 1990) and plasma levels of immunoglobulins (Muller et al. 1989) are markedly reduced in patients with diabetes mellitus type 1 , an effect reversed by insulin administration. In diabetic mice, the secretion of interleukin (IL)-4 is markedly reduced, in contrast to the secretion of IL-2 and interferon- $\gamma$, which is not affected (Wood et al. 1999). Type 2 diabetic patients show reduced thymidine uptake by lymphocytes, a reduced percentage of IL-2 receptorpositive cells and increased plasma levels of tumour necrosis factor- $\alpha$ when compared with controls (Pavelic et al. 1987, Chang \& Shaio 1995, Pickup et al. 2000). On the other hand, production of IL-2, IL-6 and IL-10 is dose- and time-dependently suppressed by elevation in glucose concentrations. High glucose levels also inhibit proliferation of peripheral mononuclear cells (Reinhold et al. 1996). Despite these changes in immune function, the effect of the diabetic state on lymphocyte metabolism has not been addressed.

The metabolism of glucose and glutamine in lymphocytes obtained from alloxan-induced diabetic rats was investigated. These metabolites are well known major fuels for lymphocytes and play a key role in the biosynthesis of ATP, DNA, RNA and phospholipids (Newsholme et al. 1999). Key enzyme activities of glycolysis (hexokinase and phosphofructokinase), pentosephosphate pathway (glucose-6-phosphate dehydrogenase; 
G6PDH), Krebs cycle (citrate synthase) and glutaminolysis (phosphate-dependent glutaminase) were determined. Decarboxylation of metabolites $\left[\mathrm{U}_{-}{ }^{14} \mathrm{C}\right]-,\left[1{ }^{14} \mathrm{C}\right]-$ and $\left[6-{ }^{14} \mathrm{C}\right]$-glucose, $\left[1-{ }^{14} \mathrm{C}\right]-$ and $\left[2-{ }^{14} \mathrm{C}\right]$-pyruvic acid, $\left[\mathrm{U}_{-}{ }^{14} \mathrm{C}\right]$-palmitic acid and $\left[\mathrm{U}_{-}{ }^{14} \mathrm{C}\right]$-glutamine were evaluated in incubated lymphocytes isolated from mesenteric lymph nodes. The measurements were carried out in cells following three experimental protocols: (1) lymphocytes freshly obtained from control and alloxaninduced diabetic rats, (2) lymphocytes from insulin-treated diabetic rats and (3) lymphocytes obtained from control and diabetic rats and cultured in the presence of insulin.

\section{Materials and methods}

\section{Reagents and enzymes}

All reagents for buffers, enzymes, bovine insulin and alloxan monohydrate were obtained from Sigma Chemical Company (St Louis, MO, USA). Neutral protomine hagedorn $(\mathrm{NPH})$ insulin for rat treatment was obtained from Biobrás (Brazil, Brazil). Culture medium RPMI1640 and supplements were purchased from Gibco BRL (Grand Island, NY, USA). [U- $\left.{ }^{14} \mathrm{C}\right]-$ Glucose $(11.3 \mathrm{GBq} /$ $\mathrm{mmol}), \quad\left[1-{ }^{14} \mathrm{C}\right]$-glucose $(2 \cdot 07 \mathrm{GBq} / \mathrm{mmol}), \quad\left[6-{ }^{14} \mathrm{C}\right]-$ glucose $(2 \cdot 07 \mathrm{GBq} / \mathrm{mmol}),\left[1-{ }^{14} \mathrm{C}\right]$-pyruvic acid $(9 \cdot 25$ $\mathrm{GBq} / \mathrm{mmol}), \quad\left[2-{ }^{14} \mathrm{C}\right]$-pyruvic acid $(9 \cdot 36 \mathrm{GBq} / \mathrm{mmol})$, $\left[\mathrm{U}_{-}{ }^{14} \mathrm{C}\right]$-palmitic acid $(9 \cdot 257 \mathrm{MBq} / \mathrm{mmol})$ and $\left[\mathrm{U}_{-}{ }^{14} \mathrm{C}\right]-$ glutamine $(8.47 \mathrm{GBq} / \mathrm{mmol})$ were obtained from Amersham International plc (Amersham, Bucks, UK).

\section{Animals}

Male Wistar rats, weighing $220 \pm 20 \mathrm{~g}$, obtained from the Department of Physiology and Biophysics, Institute of Biomedical Sciences, University of São Paulo, were used in this study. Animals were fed ad libitum and maintained in a room at $23^{\circ} \mathrm{C}$, with lights on from 0700 to $1900 \mathrm{~h}$. The Institute of Biomedical Sciences Animal Experimental Committee, University of São Paulo granted ethical approval for these studies.

\section{Induction of diabetes}

The rats were either untreated (control group injected with saline, $0.9 \% \mathrm{NaCl}$ ) or intravenously injected with alloxan (dissolved in saline solution, $\mathrm{pH} 7$ ) at a dose of $40 \mathrm{mg} / \mathrm{kg}$ body weight, after an overnight fasting period (Pereira et al. 1994). The diabetic rats used were those with glycaemia over $200 \mathrm{mg} / \mathrm{dl}$, after 7 days of alloxan injection. A group of diabetic rats was also treated with $\mathrm{NPH}$ insulin through s.c. administration of $2 \mathrm{U} /$ rat for 3 days.

\section{Experimental procedure}

Diabetic rats and matching controls were kept under similar conditions. After 7 days, the fed rats were killed by decapitation without anaesthesia between 0800 and $1100 \mathrm{~h}$. Mesenteric lymph nodes were dissected and lymphocytes were prepared as previously described (Curi et al. 1988). After centrifugation at $1200 \mathrm{~g}$ for $10 \mathrm{~min}$, lymphocytes were suspended in phosphate-buffered saline (PBS; $0 \cdot 137 \mathrm{M} \mathrm{NaCl}, 2 \cdot 7 \mathrm{mM} \mathrm{KCl}, 8 \cdot 0 \mathrm{mM} \mathrm{Na}_{2} \mathrm{HPO}_{4}$, $\mathrm{pH} 7 \cdot 4)$ and the determinations of metabolite decarboxylation and enzyme activities were determined in these cells.

The number of viable cells (>95\%) was determined in a Neubauer chamber using an optical microscope (NikonYS2-H), following the addition of Trypan Blue aqueous solution $(1 \% \mathrm{w} / \mathrm{v})$.

\section{Cell culture}

Lymphocytes obtained from control and diabetic rats were cultured at $37^{\circ} \mathrm{C}$ in an air $/ \mathrm{CO}_{2}$ atmosphere at a density of $1 \times 10^{7}$ cells in $1 \mathrm{ml}$ RPMI-1640 medium supplemented with $10 \%$ foetal calf serum, containing $5.6 \mathrm{mM}$ glucose, $2 \mathrm{mM}$ glutamine and antibiotics (100 units $/ \mathrm{ml}$ streptomycin and 200 units $/ \mathrm{ml}$ penicillin) in the presence of $1 \mathrm{mU} / \mathrm{ml}$ insulin for $6 \mathrm{~h}$. This activity of insulin corresponds to the maximal biological response of skeletal muscle to insulin during a 1-h incubation (Ceddia et al. 1998). The cells were then collected, washed with PBS and used for enzymatic activity assays and/or measurements of glucose and glutamine oxidation. The cells obtained from rats or culture plates were disrupted through sonication (Vibra Cell, Manchester, CT, USA) as previously described (Otton et al. 1998).

\section{Incubation procedure for determination of metabolite decarboxylation}

Lymphocytes $\left(1 \times 10^{7}\right)$ were incubated for $60 \mathrm{~min}$ at $37^{\circ} \mathrm{C}$ in $1 \mathrm{ml}$ phosphate buffer with $2 \%$ (w/v) defatted serum albumin. The following labelled metabolites were used: [U- $\left.{ }^{14} \mathrm{C}\right]-,\left[1-{ }^{14} \mathrm{C}\right]-$ and $\left[6-{ }^{14} \mathrm{C}\right]$-glucose $(5 \cdot 6 \mathrm{mM}$ and $0 \cdot 2 \mu \mathrm{Ci} / \mathrm{ml}),\left[1-{ }^{14} \mathrm{C}\right]-$ and $\left[2-{ }^{14} \mathrm{C}\right]$-pyruvic acid $(2 \cdot 0 \mathrm{mM}$ and $0.2 \mu \mathrm{Ci} / \mathrm{ml}),\left[\mathrm{U}_{-}{ }^{14} \mathrm{C}\right]$-palmitic acid $(0 \cdot 9 \mathrm{mM}$ and $0 \cdot 2 \mu \mathrm{Ci} / \mathrm{ml})$ and $\left[\mathrm{U}_{-}{ }^{14} \mathrm{C}\right]$-glutamine $(2 \mathrm{mM}$ and $0 \cdot 2 \mu \mathrm{Ci} / \mathrm{ml})$. The incubation was stopped by adding $0.2 \mathrm{ml}$ perchloric acid solution (25\%). ${ }^{14} \mathrm{CO}_{2}$ produced from these metabolites was collected as previously described (Ceddia et al. 1998) in a special apparatus containing phenylethylamine and methanol solution (1:1) and the radioactivity counted in a Beckman-LS 5000TD scintillator (Beckman Instruments, Fullerton, CA, USA).

\section{Assay of enzyme activities}

The activities of hexokinase (E.C. 2·7·1·1), G6PDH (E.C. $1 \cdot 1 \cdot 1 \cdot 49$ ), phosphofructokinase (E.C. $2 \cdot 7 \cdot 1 \cdot 11$ ), citrate synthase (E.C. $4 \cdot 1 \cdot 3 \cdot 7$ ) and phosphate-dependent glutaminase (E.C. $4 \cdot 1 \cdot 3 \cdot 7$ ) were determined as described 


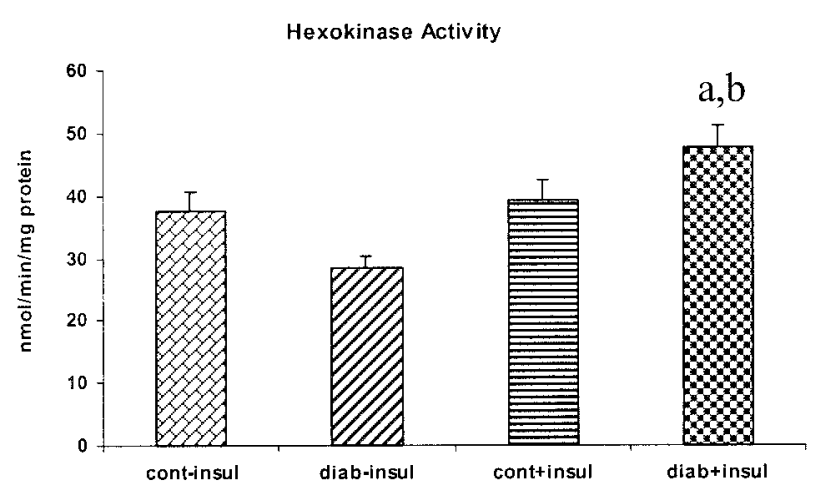

Glucose 6-phosphate dehydrogenase Activity
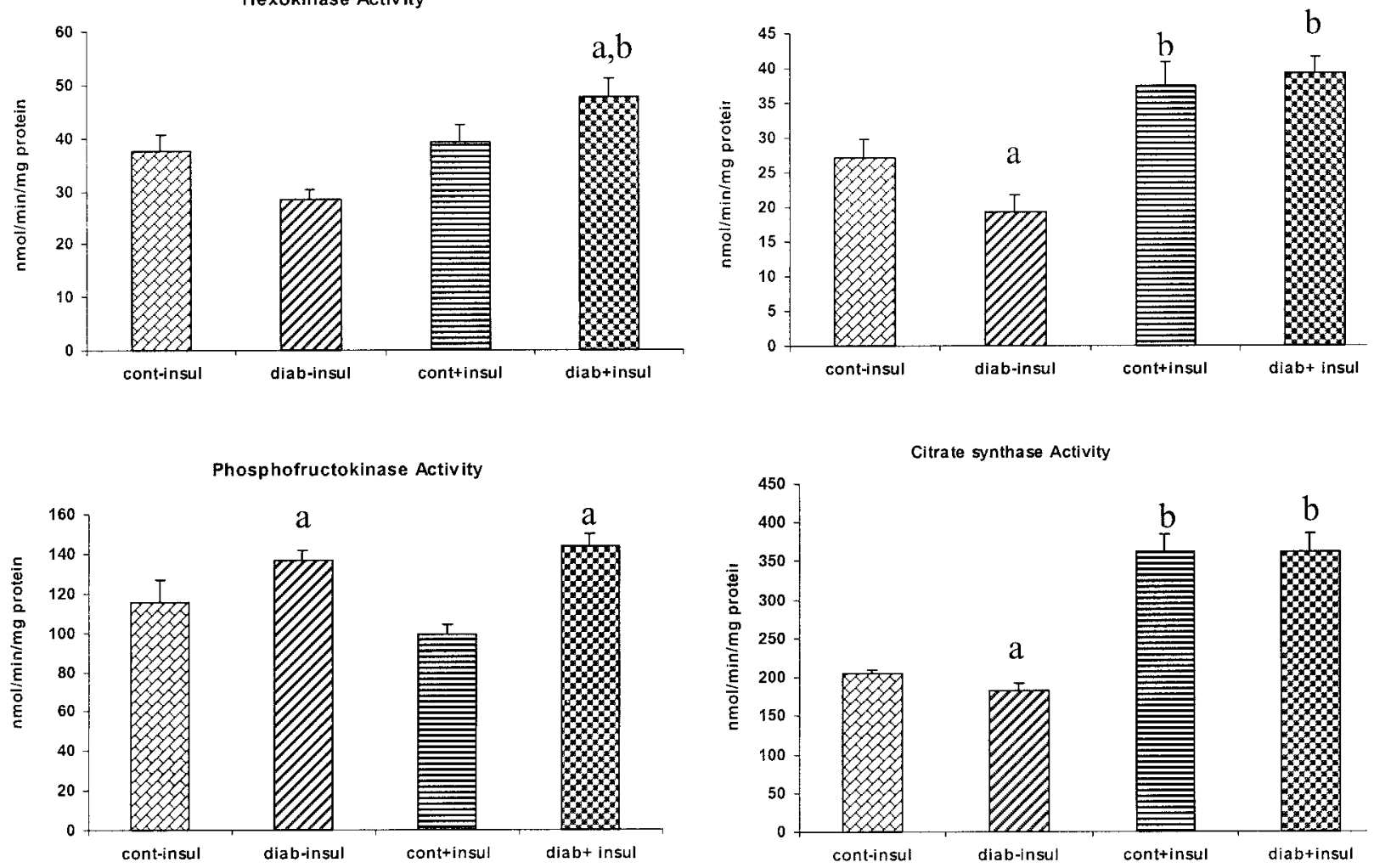

Figure 1 Maximal enzyme activities of 6-h cultured lymphocytes obtained from control and alloxan-induced diabetic rats. The control (cont) and diabetic (diab) cells were cultured in the absence $(-)$ or presence $(+)$ of insulin $\left(1 \mathrm{mU} / 10^{7}\right.$ cells). The enzyme activities are expressed as $\mathrm{nmol} / \mathrm{min}$ per $\mathrm{mg}$ protein. The values are presented as means \pm S.E.M. of ten determinations from five rats per group. ${ }^{\mathrm{a}} P<0.05$ for comparison between the respective diabetic and control groups. ${ }^{\mathrm{b}} \mathrm{P}<0.05$ due to the effect of insulin.

in our previous studies (Cooney et al. 1986, Newsholme et al. 1986, Pereira et al. 1994, Otton et al. 1998) and in other studies (Mansour 1963).

\section{Spectrophotometric conditions of the enzyme assays}

Activities of hexokinase, G6PDH and phosphofructokinase were assayed at $25^{\circ} \mathrm{C}$ and that of glutaminase at $37^{\circ} \mathrm{C}$. Citrate synthase activity was assayed by following the rate of change in absorbance at $412 \mathrm{~nm}$ and the remaining enzymes at $340 \mathrm{~nm}$. The final volume of the assay mixtures in all cases was $1.0 \mathrm{ml}$. The production of $\mathrm{NADH}$ or NADPH was monitored in a Pharmacia Biotech spectrophotometer (model Ultrospec 3000).

\section{Protein determination}

The protein content of the cells was measured by the method of Bradford (1976), using bovine serum albumin as standard.

\section{Statistical analysis}

Enzyme activities are expressed as nmol substrate utilized/ min per mg protein. The decarboxylation of $\left[\mathrm{U}_{-}{ }^{14} \mathrm{C}\right]-$,
[1- $\left.{ }^{14} \mathrm{C}\right]-$ and $\left[6-{ }^{14} \mathrm{C}\right]$-glucose, $\left[1-{ }^{14} \mathrm{C}\right]-$ and $\left[2-{ }^{14} \mathrm{C}\right]-$ pyruvic acid, [U- $\left.{ }^{14} \mathrm{C}\right]$-palmitic acid and [U- $\left.{ }^{14} \mathrm{C}\right]-$ glutamine by incubated lymphocytes is expressed as $\mathrm{nmol} / \mathrm{h}$ per $10^{7}$ cells. The results are presented as means \pm S.E.M. for five rats, as indicated in Fig. 1. $P<0 \cdot 05$ was taken to indicate significant differences between groups using ANOVA.

\section{Results}

The effect of alloxan-induced diabetes on the metabolism of freshly obtained lymphocyte is presented in Table 1. Diabetes decreased decarboxylation of $\left[\mathrm{U}_{-}{ }^{14} \mathrm{C}\right]-(27 \%)$ and $\left[6-{ }^{14} \mathrm{C}\right]$-glucose $(50 \%),\left[1-{ }^{14} \mathrm{C}\right]-(23 \%)$ and $\left[2-{ }^{14} \mathrm{C}\right]-$ pyruvate $(36 \%)$ and $\left[\mathrm{U}_{-}{ }^{14} \mathrm{C}\right]$-glutamine $(33 \%)$ in $1-\mathrm{h}$ incubated lymphocytes, whereas the decarboxylation of $\left[1-{ }^{14} \mathrm{C}\right]$-glucose was not affected. $\left[\mathrm{U}_{-}{ }^{14} \mathrm{C}\right]$-palmitic acid decarboxylation, on the other hand, was higher $(50 \%)$ in lymphocytes obtained from diabetic rats. Hexokinase activity was decreased (20\%) in lymphocytes from diabetic rats as compared with control. Diabetes also decreased G6PDH activity (18\%) and increased that of phosphofructokinase $(53 \%)$. Citrate synthase activity was decreased 
Table 1 Metabolic parameters evaluated in lymphocytes freshly obtained from control and alloxan-induced diabetic rats. Incubations for the measurement of metabolite decarboxylation were performed for $1 \mathrm{~h}$ except for palmitic acid, which was carried out for $6 \mathrm{~h}$. Decarboxylation is expressed as $\mathrm{nmol} / \mathrm{h}$ per $10^{7}$ cells. The enzyme activities were determined in freshly prepared lymphocyte homogenates and expressed as $\mathrm{nmol} / \mathrm{min}$ per $\mathrm{mg}$ protein. Values are means \pm S.E.M. of ten determinations from five rats per group

\begin{tabular}{|c|c|c|}
\hline & \multicolumn{2}{|l|}{ Groups } \\
\hline & Control & Diabetic \\
\hline \multicolumn{3}{|l|}{ Parameters } \\
\hline${ }^{14} \mathrm{CO}_{2}$ from $\left[\mathrm{U}-{ }^{14} \mathrm{C}\right]$-glucose & $13 \cdot 1 \pm 0 \cdot 81$ & $9 \cdot 50 \pm 0.59^{a}$ \\
\hline${ }^{14} \mathrm{CO}_{2}$ from $\left[1-{ }^{14} \mathrm{C}\right]$-pyruvate & $7 \cdot 52 \pm 0 \cdot 22$ & $5 \cdot 81 \pm 0 \cdot 39^{a}$ \\
\hline${ }^{14} \mathrm{CO}_{2}$ from $\left[2-{ }^{14} \mathrm{C}\right]$-pyruvate & $6 \cdot 04 \pm 0 \cdot 47$ & $3 \cdot 83 \pm 0.43^{a}$ \\
\hline${ }^{14} \mathrm{CO}_{2}$ from $\left[1-{ }^{14} \mathrm{C}\right]$-glucose & $0.79 \pm 0.06$ & $0 \cdot 98 \pm 0 \cdot 13$ \\
\hline${ }^{14} \mathrm{CO}_{2}$ from $\left[6-{ }^{14} \mathrm{C}\right]$-glucose & $0 \cdot 70 \pm 0.08$ & $0 \cdot 35 \pm 0.07^{a}$ \\
\hline${ }^{14} \mathrm{CO}_{2}$ from $\left[\mathrm{U}-{ }^{14} \mathrm{C}\right]$-glutamine & $13 \cdot 1 \pm 1 \cdot 08$ & $8 \cdot 69 \pm 0.54^{\mathrm{a}}$ \\
\hline${ }^{14} \mathrm{CO}_{2}$ from $\left[\mathrm{U}-{ }^{14} \mathrm{C}\right]$-palmitic acid & $0 \cdot 76 \pm 0.08$ & $1 \cdot 56 \pm 0 \cdot 24^{a}$ \\
\hline Hexokinase activity & $33 \cdot 8 \pm 1 \cdot 36$ & $28 \cdot 6 \pm 0.99^{a}$ \\
\hline G6PDH activity & $23 \cdot 2 \pm 1 \cdot 03$ & $19 \cdot 1 \pm 1 \cdot 30^{\mathrm{a}}$ \\
\hline Citrate synthase activity & $163 \pm 11 \cdot 5$ & $98 \cdot 6 \pm 5 \cdot 15^{a}$ \\
\hline Phosphofructokinase activity & $90 \cdot 9 \pm 6 \cdot 53$ & $139 \pm 11 \cdot 6^{a}$ \\
\hline Glutaminase activity & $24 \cdot 4 \pm 1 \cdot 76$ & $25 \cdot 1 \pm 1 \cdot 68$ \\
\hline
\end{tabular}

a $P<0.05$ compared with control rats.

(40\%), whereas that of phosphate-dependent glutaminase activity was not modified in diabetic lymphocytes.

Insulin treatment ( $2 \mathrm{U} /$ day) of the rats was performed in order to abolish the metabolic changes induced by diabetes (data not shown). The decrease in $\left[\mathrm{U}_{-}{ }^{14} \mathrm{C}\right]$-glucose decarboxylation induced by diabetes was fully reversed by insulin administration, the value obtained in the treated group being $29 \%$ higher than in control rats. The decrease in the activity of G6PDH in diabetic lymphocytes was also abolished by insulin treatment, being 30\% higher than in control cells. The decrease in citrate synthase activity of diabetic lymphocytes was partially recovered by insulin injection, whereas the increase in phosphofructokinase activity caused by diabetes was abolished by the hormonal treatment.

Experiments using lymphocytes in culture were performed to evaluate whether the metabolic alterations observed in freshly obtained lymphocytes were due to the lack of insulin only and whether the addition of this hormone to the medium would be able to fully reverse the changes induced by diabetes. Results of the enzyme activities obtained from lymphocytes cultured for $6 \mathrm{~h}$ in the presence or absence of $1 \mathrm{mU}$ insulin are shown in Fig. 1. Maximum activities of hexokinase, G6PDH and citrate synthase returned to control values after the addition of insulin to the medium. This hormone, however, did not affect phosphofructokinase activity. Similarly, the presence of insulin fully reversed the alterations observed in the decarboxylation of $\left[\mathrm{U}_{-}{ }^{14} \mathrm{C}\right]-$ and $\left[6-{ }^{14} \mathrm{C}\right]$-glucose, $\left[1-{ }^{14} \mathrm{C}\right]-$ and $\left[2-{ }^{14} \mathrm{C}\right]$-pyruvate and $\left[\mathrm{U}-{ }^{14} \mathrm{C}\right]$-glutamine induced by diabetes.

\section{Discussion}

The purpose of this study was to examine the effect of the diabetic condition on lymphocyte metabolism. This was the reason for choosing the model of alloxan-induced diabetes. Alloxan-diabetic rats present low plasma levels of insulin with no change in the activation state of the immune cells. Leukocyte activation is well known to occur in spontaneously diabetic Bio Breeding rats (Field et al. 1990) and patients (Conroy et al. 2000) and is the major cause of the pathogenesis of diabetes. Therefore, the use of lymphocytes from genetically diabetic rats and diabetic patients was not considered appropriate for the purpose of this study.

The results presented herein indicate that lymphocytes obtained from alloxan-induced diabetic rats show marked changes in glucose and glutamine metabolism. Impairment in the ability of lymphocytes to utilize glucose and glutamine could significantly affect their capacity to respond to immune stimuli. The important role of insulin for lymphocyte metabolism was confirmed by the fact that insulin treatment either in vivo or in vitro reversed most of the changes observed in Table 1.

In addition to glucose decarboxylation, the measurement of glucose utilization and lactate production was also performed in 1-h incubated cells. Glucose utilization and lactate production were raised by $20 \%$ and $2 \cdot 2$-fold respectively in diabetic lymphocytes (data not shown). Despite the increase in glucose uptake, diabetic lymphocytes were not able to oxidize this metabolite efficiently. Similar observations have been previously reported in thymus lymphocytes from streptozotocininduced diabetic rats (Moreno-Aurioles et al. 1996).

Pyruvate is a common product of glucose and glutamine metabolism in lymphocytes (Curi et al. 1988). However, the capacities for both glycolysis and glutaminolysis are very much greater than the capacity for pyruvate oxidation (Curi et al. 1988). In fact, pyruvate metabolism is partially directed to lipid synthesis in lymphocytes (Curi et al. 1999).

The rate of pyruvate oxidation in intact cells is usually measured following the conversion of $\left[1-{ }^{14} \mathrm{C}\right]$-pyruvate into ${ }^{14} \mathrm{CO}_{2}$. However, it has been pointed out that there is pyruvate carboxylase activity in rat mesenteric lymphocytes (Curi et al. 1988). Therefore, these cells can convert $\left[1-{ }^{14} \mathrm{C}\right]$-pyruvate into ${ }^{14} \mathrm{CO}_{2}$ through pyruvate dehydrogenase and the TCA cycle via pyruvate carboxylase reaction (Curi \& Newsholme 1989). In order to estimate the contribution of both decarboxylation sites of glucose (PDH and TCA cycles), measurements of ${ }^{14} \mathrm{CO}_{2}$ production from $\left[1-{ }^{14} \mathrm{C}\right]-$ and $\left[2-{ }^{14} \mathrm{C}\right]$-pyruvate were carried out. $\left[2-{ }^{14} \mathrm{C}\right]$-Pyruvate is decarboxylated through 
the TCA cycle only in opposition to $\left[1-{ }^{14} \mathrm{C}\right]$-pyruvate which produces ${ }^{14} \mathrm{CO}_{2}$ in both sites as mentioned (Curi et al. 1988). The decarboxylation of $\left[1-{ }^{14} \mathrm{C}\right]-$ and $\left[2-{ }^{14} \mathrm{C}\right]-$ pyruvate was decreased in diabetic lymphocytes as compared with the control group. Based on these findings, we can assume that the flux of metabolites through pyruvate dehydrogenase and the Krebs cycle was affected by the diabetic state. After in vitro insulin administration, decarboxylation of both $\left[1-{ }^{14} \mathrm{C}\right]-$ and $\left[2-{ }^{14} \mathrm{C}\right]$-pyruvate returned to control levels (data not shown). An increased oxidation of fatty acids (Table 1) and so the production of acetyl-CoA may be an important mechanism to inhibit PDH activity in diabetic lymphocytes (Kelley \& Mandarino 2000).

The pentose-phosphate pathway oxidizes glucose-6phosphate to intermediates of the glycolytic pathway, generating NADPH and ribose-5-phosphate for fatty acids and nucleotide synthesis respectively. This pathway can be divided into two portions: (1) an oxidative phase where glucose-6-phosphate is oxidatively decarboxylated to a pentose, ribose-5-phosphate and (2) the non-oxidative portion where intermediates of glycolytic pathway are formed. To examine the role of the pentose-phosphate pathway in the reduction of glucose oxidation found in diabetic lymphocytes, we determined the G6PDH activity and the decarboxylation of $\left[1-{ }^{14} \mathrm{C}\right]-$ and $\left[6-{ }^{14} \mathrm{C}\right]$-glucose. The productions of ${ }^{14} \mathrm{CO}_{2}$ from $\left[1-{ }^{14} \mathrm{C}\right]-$ and $\left[6-{ }^{14} \mathrm{C}\right]-$ glucose were compared with estimates of the upper limit of the pentose-phosphate pathway activity in mesenteric lymph node lymphocytes as described for other cell types (Larrabee 1989). The production of ${ }^{14} \mathrm{CO}_{2}$ from $\left[1-{ }^{14} \mathrm{C}\right]-$ glucose in the diabetic group was 0.98 compared with $0.78 \mathrm{nmol} / \mathrm{h}$ per $10^{7}$ cells for control lymphocytes. The difference between ${ }^{14} \mathrm{CO}_{2}$ production from $\left[1-{ }^{14} \mathrm{C}\right]-$ and $\left[6-{ }^{14} \mathrm{C}\right]$-glucose in diabetic lymphocytes was $0.63 \mathrm{nmol} /$ $\mathrm{h}^{-1}$ per $10^{7}$ cells compared with control lymphocytes which was $0.09 \mathrm{nmol} / \mathrm{h}$ per $10^{7}$ cells. Insulin administration in vitro returned the decarboxylation of $\left[1-{ }^{14} \mathrm{C}\right]-$ and $\left[6-{ }^{14} \mathrm{C}\right]$-glucose to control levels (data not shown). These findings support the proposition that the activity of the pentose-phosphate pathway is markedly raised in lymphocytes from diabetic rats. This occurred despite the fact that G6PDH activity was slightly lower (only 18\%) in lymphocytes from diabetic rats. In fact, the activity of this enzyme is at least 180-fold higher than the rates of glucose decarboxylation and so low changes do not affect the flux of substrates. A more pronounced decrease in G6PDH activity was reported by Costa-Rosa et al. (1996) in peritoneal macrophages obtained from alloxan-induced diabetic rats.

The presence of glucose, high activities of membrane glucose transport and of both Krebs cycle and glycolysis has been demonstrated to be necessary to maintain DNA synthesis and to sustain lymphocyte proliferation. The TCA cycle is an important source of ATP and precursors for macromolecule biosynthesis (Curi et al. 1999). Citrate synthase activity, which is an important enzyme of the TCA cycle (Newsholme et al. 1987) was significantly lower $(40 \%)$ in lymphocytes from diabetic rats (Table 1). The maximal activity of phosphofructokinase, on the other hand, was increased by the diabetic state, indicating that the capacity of glycolysis is markedly in excess of that for glucose oxidation. Citrate is an allosteric inhibitor of phosphofructokinase (Reinhold et al. 1996) and so its decrease may partially explain the increase in this enzyme activity. Although citrate synthase activity returned to control levels after insulin treatment, the same was not observed for phosphofructokinase (Fig. 1). Therefore, the mechanism involved in phosphofructokinase stimulation under these conditions remains to be elucidated. Increases of fructose 2,6-biphosphate levels and of phosphofructokinase activity have also been found in thymocytes obtained from streptozotocin-induced diabetic rats (Moreno-Aurioles et al. 1996).

Glutamine is both an oxidative substrate and an important source of nitrogen for de novo synthesis of pyrimidine and purine nucleotides and amino sugars in lymphocytes (Curi \& Newsholme 1989, Curi et al. 1999). Glutamine is well known to be required for both lymphocyte proliferation and cytokine production (Pallavicini \& William 1976, Calder \& Yaqoob 1999, Newsholme et al. 1999). We have reported here that glutamine oxidation was decreased in diabetic lymphocytes (33\%, Table 1), whereas glutaminase activity was not modified. After insulin treatment, decarboxylation of $\left[\mathrm{U}_{-}{ }^{14} \mathrm{C}\right]$-glutamine in lymphocytes from the diabetic group was similar to that of the control group (data not shown). Glutamine is mainly oxidized through the left-hand side of the TCA cycle (Curi et al. 1999). Therefore, the lower activity of citrate synthase (the first step on the right-hand side of the TCA) in diabetic lymphocytes may not explain the reduced capacity of the Krebs cycle to oxidize glutamine. In fact, decreased glutamine uptake (32\%) and glutamate production $(22 \%)$ in incubated lymphocytes obtained from diabetic rats were also found in this study (data not shown). Although glutaminase activity was not modified, a reduction in glutamine transport may occur in diabetic lymphocytes leading to a decrease in glutamine oxidation (Table 1).

Since glucose and glutamine oxidation was low, we investigated whether fatty acids could be an important source of ATP for diabetic lymphocytes. It is well known that other metabolites can enter the TCA cycle via acetyl $\mathrm{CoA}$ in lymphocytes, e.g. fatty acids and ketone bodies. Evidence has previously been obtained that $\left[{ }^{14} \mathrm{C}\right]$-oleate is converted to ${ }^{14} \mathrm{CO}_{2}$ by lymphocytes (Ardawi \& Newsholme 1984). Calder et al. (1994) demonstrated that lymphocytes utilize fatty acids originated from triacylglycerols due to the activity of lipoprotein lipase. As reported herein, lymphocytes from diabetic rats presented a greater capacity of $\left[\mathrm{U}_{-}{ }^{14} \mathrm{C}\right]$-palmitic acid decarboxylation than those from the control group. Diabetic rats and patients 
present a high plasma level of free fatty acids and triacylglycerols (Boden 1999, Kelley \& Mandarino 2000). Therefore, lymphocytes from diabetic rats may replace glucose and glutamine by an increase in fatty acid oxidation.

Changes in leukocyte metabolism, although critically important to their function, have received little attention in immunodeficient states, such as diabetes. The metabolic changes reported herein demonstrate that this could well be one of the mechanisms for the impaired immune function observed in diabetic patients.

\section{Acknowledgements}

The authors are indebted for the constant assistance of $G$ de Souza, Dr C K Miyasaka and Dr R Verlengia. This research is supported by FAPESP, CNPq and PRONEX.

\section{References}

Ardawi MS \& Newsholme EA 1984 Metabolism of ketone bodies, oleate and glucose in lymphocytes of the rat. Biochemistry 217 289-296.

Boden G 1999 Free fatty acids, insulin resistance, and type 2 diabetes mellitus. Proceedings of the Association of American Physicians 111 241-248.

Bradford M 1976 A rapid and sensitive method for the quantification of microgram quantities of protein utilising the principle of proteindye binding. Analytical Biochemistry 72 248-254.

Calder PC \& Yaqoob P 1999 Glutamine and the immune system. Amino Acids 17 227-241.

Calder PC, Yaqoob P \& Newsholme EA 1994 Triacylglycerol metabolism by lymphocytes and the effect of triacylglycerols on lymphocyte proliferation. Biochemical Journal 298 605-611.

Ceddia RB, William NW, Lima FB \& Curi R 1998 Leptin inhibits insulin-stimulated incorporation of glucose into lipids and stimulates glucose decarboxylation in isolated rat adipocytes. Journal of Endocrinology 158 R7-R9.

Chang FY \& Shaio MF 1995 Decreased cell-mediated immunity in patients with non-insulin-dependent diabetes mellitus. Diabetes Research and Clinical Practice 28 137-146.

Conroy SJ, Abdel-Wahab YHA, Caraher EM, Byrne PM, Murphy E, Nolan J, Flatt PR \& Newsholme P 2000 Evidence for complementdependent and -independent inhibition of insulin secretion from clonal B-cells incubated in the presence of sera of newly diagnosed IDDM patients. Journal of Endocrinology 164 139-147.

Cooney G, Curi R, Mitchelson P, Simpson M \& Newsholme EA 1986 Activities of some key enzymes of carbohydrate, ketone body, adenosine and glutamine metabolism in liver and brown and white adipose tissues of the rat. Biochemical and Biophysical Research Communications 138 687-692.

Costa-Rosa LFBP, Safi DA, Cury Y \& Curi R (1996) The effect of insulin on macrophage metabolism and function. Cell Biochemistry and Function 14 33-42.

Curi R \& Newsholme EA 1989 The effect of adenine nucleotides on the rate and fate of glutamine utilisation by incubated mitochondria isolated from rat mesenteric lymph nodes. Molecular and Cellular Biochemistry 86 71-76.

Curi R, Newsholme P \& Newsholme EA 1988 Metabolism of pyruvate by isolated rat mesenteric lymphocyte, lymphocyte mitochondria and isolated mouse macrophages. Biochemical Journal 250 383-388.

Curi R, Newsholme P, Pithon-Curi TC, Pires-de-Melo M, Garcia C, Homem-de-Bittencourt PI Jr \& Guimarães ARP 1999 Metabolic fate of glutamine in lymphocytes, macrophages and neutrophils. Brazilian Journal of Medical and Biological Research 32 15-21.

Eliopoulos GM 1995 Diabetes and infection. In Principles and Practice of Endocrinology and Metabolism, edn 2, p 1303-1420. Eds KL Becker, CR Kahn \& L Kenneth. Philadelphia: JB Lippincott.

Field CJ, Wu G, Metroz-Dayer MD, Montambault M \& Marliss EB 1990 Lactate production is the major metabolic fate of glucose in splenocytes and is altered in spontaneously diabetic BB rats. Biochemical Journal 272 445-452.

Garcia-Leme J 1989 Hormones and Inflammation, pp 165-214. Boca Raton: CRC Press.

Kelley DE \& Mandarino LJ 2000 Fuel selection in human skeletal muscle in insulin resistance: a reexamination. Diabetes $\mathbf{4 9}$ $677-683$

Korfel J, Kinalsha I, Rogowski F \& Citko A 1990 Cellular immunity in insulin-dependent diabetes mellitus. Polski Tygodnik Lekarski $\mathbf{4 5}$ 373-375.

Kraine MR \& Tisch RM 1999 The role of environmental factors in insulin dependent diabetes mellitus: an unresolved issue. Environmental Health Perspectives 107 777-781.

Larkin JG, Frier BM \& Ireland J 1985 Diabetes mellitus and infection. Postgraduate Medical Journal 61 233-237.

Larrabee MG 1989 The pentose cycle (hexose monophosphate shunt) Journal of Biological Chemistry 264 15875-15879.

Mansour TE 1963 Studies on heart phosphofructokinase: purification, inhibition and activation. Journal of Biological Chemistry 238 2285-2292.

Moreno-Aurioles VR, Montaño R, Conde M, Bustos R \& Sobrino F 1996 Streptozotocin-induced diabetes increases fructose 2,6biphosphate levels and glucose metabolism in thymus lymphocytes. Life Sciences 58 477-484.

Muller C, Zielinski CC, Kalinowski W, Wolf H, Mannhalter JW, Aschauer-Treiber G, Klosch-Kasparek D, Gaube S, Eibl MM \& Schernthaner G 1989 Effects of cyclosporin A upon humoral and cellular immune parameters in insulin-dependent diabetes mellitus type I: a long-term follow-up study. Journal of Endocrinology 121 177-183.

Newsholme P, Curi R, Gordon S \& Newsholme EA 1986 Metabolism of glucose, glutamine, long-chain fatty acids and ketone bodies by murine macrophages. Biochemical Journal 239 121-125.

Newsholme P, Gordon S \& Newsholme EA 1987 Rates of utilisation and fates of glucose, glutamine, pyruvate, fatty acids and ketone bodies by mouse macrophages. Biochemical Journal 242 631-636.

Newsholme P, Curi R, Pithon Curi TC, Murphy CJ, Garcia C \& Pires-de-Melo M 1999 Glutamine metabolism by lymphocytes, macrophages, and neutrophils: its importance in health and disease. Journal of Nutritional Biochemistry 10 316-324.

Otton R, Graziola F, Souza JAA, Curi TCP, Hirata MH \& Curi R 1998 Effect of dietary fat on lymphocyte proliferation and metabolism. Cell Biochemistry and Function 16 253-259.

Pallavicini MG \& William KN 1976 Inhibition of lymphocyte blastogenesis by factor(s) in alloxan-diabetic rat plasma. Diabetes $\mathbf{2 5}$ 614-622.

Pavelic K, Bernacki RJ \& Vuk-Pavlovic S 1987 Insulin-modulated interleukin-2 production by murine splenocytes and T-cell hybridoma. Journal of Endocrinology 114 89-94.

Pereira B, Costa Rosa LFB, Safi DA, Bechara EJH \& Curi R 1994 Superoxide dismutase, catalase and glutathione peroxidase activities in the lymphoid organs of diabetic rats. Journal of Endocrinology 142 $161-165$. 
Pickup JC, Chusney GD, Thomas SM \& Burt D 2000 Plasma interleukin-6, tumour necrosis factor alpha and blood cytokine production in type 2 diabetes. Life Sciences 67 291-295.

Reinhold D, Ansorge S \& Schleicher ED 1996 Elevated glucose levels stimulate transforming growth factor- $\beta 1$ (TGF- $\beta 1$ ), suppress interleukin IL-2, IL-6 and IL-10 production and DNA synthesis in peripheral blood mononuclear cells. Hormone and Metabolic Research 28 267-270.
Wood SC, Rao TD \& Frey AB 1999 Multidose streptozotocin induction of diabetes in $\mathrm{BALB} / \mathrm{cBy}$ mice induces a $\mathrm{T}$ cell proliferation defect in thymocytes which is reversible by interleukin-4. Cell Immunology 192 1-12.

Received in final form 29 January 2002 Accepted 7 March 2002 